Aspirasi: Jurnal Masalah-Masalah Sosial | Volume 11, No. 1 Juni 2020

ISSN: 2086-6305 (print) ISSN: 2614-5863 (electronic)

doi: 10.22212/aspirasi.v11i1.1587

link online: http://jurnal.dpr.go.id/index.php/aspirasi/index

\title{
Ocean Grabbing di Indonesia dan Malaysia: Catatan Krisis Sosio-Ekologis Dampak Proyek Reklamasi
}

\author{
Ocean Grabbing in Indonesia and Malaysia: Notes of the Socio-Ecological Crisis \\ due to Reclamation Projects
}

Anggalih Bayu Muh. Kamim

anggalih.bayu@yahoo.co.id

Alumnus Departemen Politik \& Pemerintahan FISIPOL UGM

Naskah diterima: 23 Maret 2020 | Naskah direvisi: 28 Mei 2020 | Naskah diterbitkan: 30 Juni 2020

\begin{abstract}
This study explores the ocean grabbing phenomenon that arises as a result of the reclamation project undertaken to facilitate the expansion of urban capital. The case of reclamation projects in Indonesia and Malaysia is taken to be compared with the consideration of the method of spending and facilitation on urban capital investment through the reclamation project. The need for new land which has become the culprit of the reclamation project will be explored about the impact it has had on the socio-ecological crisis that coastal communities must suffer. This study is a literature review carried out by tracing research reports, journal articles, and online media coverage related to the problem being examined. This study was carried out by borrowing the definition of ocean grabbing made by Bennett, Govan, and Satterfield and the criteria they made to show socio-ecological crises arising in coastal communities due to the reclamation project. The results of the study show that reclamation projects in Indonesia and Malaysia pose serious ocean grabbing problems. First, reclamation projects in Indonesia and Malaysia have poor governance. Minimal public participation and inadequate planning are a way for the facilitation of urban capital expansion in the reclamation project. Second, the reclamation project has worsened the living conditions of coastal communities due to loss of catchment area, decreased income, and deprived the community of its living space. Third, the reclamation project has caused damage to the ecosystem which has broken the balance of the environment in marine waters.
\end{abstract}

Keywords: investment; ocean grabbing; reclamation project

Abstrak: Kajian ini mendalami fenomena ocean grabbing yang muncul akibat proyek reklamasi yang dilakukan untuk memfasilitasi ekspansi modal. Kasus proyek reklamasi di Indonesia dan Malaysia diambil untuk diperbandingkan dengan melihat metode pengurugan dan upaya memfasilitasi investasi perkotaan dalam proyek reklamasi. Kebutuhan lahan baru yang menjadi biang keladi dari proyek reklamasi akan didalami mengenai dampak yang ditimbulkannya pada krisis sosio-ekologis yang harus diderita masyarakat pesisir. Studi ini adalah kajian pustaka yang dilakukan dengan menelusuri laporan penelitian, artikel jurnal, dan pemberitaan media daring yang terkait dengan persoalan yang dikaji. Kajian ini dilakukan dengan meminjam pendefinisian ocean grabbing yang dibuat oleh Bennett, Govan, dan Satterfield serta kriteria yang mereka buat untuk mengidentifikasi krisis sosio-ekologis yang muncul di masyarakat pesisir akibat proyek reklamasi. Hasil kajian menunjukkan bahwa proyek reklamasi di Indonesia dan Malaysia menimbulkan masalah ocean grabbing secara serius. Pertama, proyek reklamasi di Indonesia dan Malaysia memiliki tata kelola yang buruk. Partisipasi publik yang minim dan perencanaan tidak memadai menjadi jalan bagi fasilitasi ekspansi modal dalam proyek reklamasi. Kedua, proyek reklamasi telah memperburuk keadaan kehidupan masyarakat pesisir akibat hilangnya daerah tangkapan, penurunan pendapatan, dan mencerabut komunitas dari ruang hidupnya. 
Ketiga, proyek reklamasi menyebabkan kerusakan ekosistem yang telah merusak keseimbangan lingkungan di perairan laut.

Kata Kunci: investasi; ocean grabbing; proyek reklamasi

\section{Pendahuluan}

Tulisan ini akan mendalami upaya reklamasi pantai di Indonesia dan Malaysia untuk memfasilitasi keperluan investasi perkotaan yang menyebabkan tergerusnya kesatuan hidup di wilayah pesisir dan perairan laut setempat. Penyakit lapar tanah yang muncul dari upaya memfasilitasi ekspansi perkotaan telah mendorong penciptaan ruang yang menggerus perairan laut bersama dengan kehidupan di sekitarnya. Tidak hanya kehidupan warga sekitar pesisir yang menggantungkan hidupnya pada laut, upaya reklamasi pantai di perkotaan di Indonesia dan Malaysia telah mendorong kerusakan serius pada ekosistem akibat ekspansi modal.

Reklamasi di Indonesia dan Malaysia dipilih untuk diperbandingkan disebabkan memiliki persamaan dalam hal keterlibatan developer yang melakukan pengembangan properti eksklusif yang mendorong semakin teralienasi kehidupan masyarakat pesisir dan rusaknya ekosistem perairan laut. Abdullah' dan Loi (1992: 2-4) menjelaskan bahwa reklamasi pantai di Malaysia dimulai pada tahun 1970-an dengan upaya memfasilitasi penambahan jumlah populasi perkotaan dan industrialisasi. Permintaan akan lahan yang makin menggila menyebabkan konsorsium bisnis dan pemerintah melakukan reklamasi untuk menyelesaikan problem lapar tanah. Kekuatan pasar menurut Abdullah' \& Loi (1992: 2-4) mendorong permintaan pembuatan ruang yang makin meluas di wilayah pesisir. Reklamasi di Penang, Melaka, dan Labuan menjadi pionir proyek yang terus meluas di berbagai penjuru Malaysia (Abdullah' \& Loi, 1992: 2-4).

Mohamed dan Razman (2018: 25-27) menemukan bahwa reklamasi di Melaka terjadi disebabkan adanya transformasi ekonomi politik wilayah pesisir Malaysia yang berubah dari sektor agraris menjadi sektor jasa dan industri. Industrialisasi dan berkembangnya pariwisata telah mendorong adanya permintaan lahan untuk pengembangan penginapan dan pusat perbelanjaan untuk memfasilitasi peningkatan wisatawan (Mohamed \& Razman, 2018: 25-27).

Yusup, Arshad, Abdullah, dan Ishak (2015: 358-359) menemukan masalah serius dalam kebijakan yang dibuat untuk memfasilitasi reklamasi di Melaka, Malaysia. Proyek reklamasi tidak didukung oleh arahan pembangunan yang memadai dan semata melibatkan insting dari kekuatan pasar untuk membentuk ruang perkotaan baru di perairan laut. Antara pemerintah pusat dan pemerintah lokal tidak memiliki kesepahaman bersama terkait dengan proyek reklamasi dan membuat skema masingmasing yang menguntungkan konsorsium bisnis (Yusup et al., 2015: 358-359).

Reklamasi secara masif untuk keperluan perluasan modal perkotaan juga terjadi di Indonesia. Koalisi Rakyat untuk Keadilan Perikanan (KIARA) mencatat bahwa sampai dengan saat ini ada 41 proyek reklamasi di Indonesia untuk keperluan investasi yang telah mendorong kerusakan ekologis di wilayah pesisir dan perairan laut. Pemerintah melihat potensi yang besar dari wilayah pesisir untuk pengembangan properti yang dilihat akan menjadi pusat perekonomian baru (Ambari, 2019). Data dari Kementerian Kelautan dan Perikanan mencatat ada 37 lokasi yang akan dikembangkan melalui reklamasi, di mana 17 proyek telah berjalan (Himawan \& Tolen, 2016).

Ruslin (2017: 186-188) telah melihat bahwa proses reklamasi pantai menjadi bentuk riil dari wajah poskolonial Indonesia. Proyek reklamasi menunjukkan bahwa masyarakat pesisir tidak terjajah secara langsung oleh pihak asing, tetapi justru langsung di bawah penguasa setempat yang menindas. Kemakmuran dari proyek reklamasi menjadi hanya dirasakan oleh segelintir orang yang berada dalam jejaring kekuasaan. Proyek reklamasi menjadi wajah dari mesin ekstraktif negara yang berusaha memperoleh ceruk keuntungan dari pasar yang berkembang (Ruslin, 2017: 186-188).

Pemerintah daerah di mana proyek reklamasi berlangsung juga tidak memiliki kebijakan yang 
memadai untuk melindungi perairan laut dan wilayah pesisir. Mulai dari upaya kebijakan zonasi sampai dengan izin lingkungan sering kali tidak dimiliki oleh pemerintah daerah (Maulidiyah, 2016: 61-65). Di Indonesia surat keputusan pemerintah daerah provinsi atau kabupaten/kota menjadi izin yang dikeluarkan untuk memfasilitasi reklamasi di daerah (Kalalo, 2009: 115-117).

Penguasa menurut Mahdi (2017: 40-42) menjadikan proyek reklamasi sebagai jalan tercepat untuk mendapatkan pendapatan daerah. Penguasa menjadikan proyek reklamasi sebagai alat kekuasaannya. Proyek reklamasi membawa keuntungan bagi pebisnis yang difasilitasi oleh penguasa (Mahdi, 2017: 40-42). Investasi modal yang dilakukan dalam proyek reklamasi sebenarnya adalah sebuah proses historis yang menunjukkan adanya tarik-menarik kepentingan (Amanda, Ngenget, \& Makhdor, 2017: 112-115).

Sayangnya, kajian terkait reklamasi di Malaysia dan Indonesia tersebut belum menggali mengenai fenomena penyakit lapar tanah yang menyebabkan kerusakan perairan laut dan wilayah pesisir. Kajian ini akan lebih jauh mendalami fenomena lapar tanah yang didorong oleh ekspansi modal yang memaksa pembentukan ruang baru melalui reklamasi di Indonesia dan Malaysia. Penyakit lapar tanah sendiri diidentifikasi sebagai kondisi predatoris dari pasar yang membutuhkan ruang baru untuk keperluan akumulasi modalnya. Di mana proses reklamasi akibat penyakit lapar tanah telah mendorong gejala ocean grabbing, yakni tercerabutnya ekosistem pesisir dan perairan laut akibat proses akumulasi modal.

Kajian ini akan dilakukan dengan studi pustaka terhadap berbagai dokumen untuk menjawab pertanyaan penelitian bagaimana penyakit lapar tanah mendorong terjadinya ocean grabbing dalam proyek reklamasi di Indonesia dan Malaysia? Pengumpulan data dilakukan dengan melakukan penelusuran terhadap laporan pemerintahan, artikel jurnal, laporan penelitian, dan pemberitaan media daring yang terkait dengan topik yang dikaji. Analisis data dilakukan melalui tahapan reduksi data, penyajian data, verifikasi, dan penarikan kesimpulan.

\section{Ocean Grabbing dan Krisis Sosio-Ekologis di Ekosistem Perairan Laut}

Kajian ini akan dibingkai dengan teori ocean grabbing untuk menggali ekspansi modal yang memicu proyek reklamasi yang menyebabkan kerusakan ekosistem perairan laut dan pesisir di Indonesia dan Malaysia. Ekspansi modal yang membutuhkan lahan baru mendorong pembuatan daratan baru, demi kepentingan akumulasi.

Grydehøj (2015: 107-109) telah menggali bagaimana proyek reklamasi di Bahrain, Kopenhagen, Dubai, Hong Kong, Makau, New York, dan Xiamen menjadi bentuk dari akumulasi modal melalui proses perampasan. Menurut Grydehøj (2015: 108), reklamasi mendorong keterbatasan akses publik terhadap ruang baru yang telah diciptakan oleh modal. Reklamasi menjadi bentuk akumulasi modal melalui perampasan dengan mentransformasikan sumber daya laut menjadi aset pribadi elite yang berbentuk tanah solid dan statis (Grydehøj, 2015: 109).

Namun, penelitian mengenai ekspansi modal perkotaan di wilayah pesisir dan perairan laut melalui proyek reklamasi belum mampu menggali efek langsungnya terhadap perampasan ekosistem setempat. Studi mengenai perampasan di perairan laut kerap disebut dengan ocean grabbing. Menurut Transnational Institute (TNI) (2014: 3-5), ocean grabbing dimaknai sebagai segala proses negatif yang memengaruhi komunitas, cara hidup, identitas budaya, dan mata pencaharian tergantung pada keterlibatan mereka dalam penangkapan ikan skala kecil dan kegiatan yang terkait.

Perampasan laut berarti memberikan kendali pada aktor ekonomi untuk terlibat dalam proses pengambilan keputusan, termasuk kekuatan untuk memutuskan bagaimana dan apa peruntukan sumber daya laut digunakan (Transnational Institute, 2014: 5-7). Ocean grabbing sebenarnya tidak hanya melibatkan terganggunya perikanan di laut, tapi juga meliputi perairan sungai, danau, delta dan lahan basah, ekosistem bakau dan terumbu karang.

Bennett, Govan, dan Satterfield (2015: 62-63) mengkritik pemaknaan sempit yang digunakan oleh TNI dengan mendefinisikan ocean grabbing 
sebagai pengambilan kontrol, akses, dan penguasaan ruang perairan laut dari pengguna sebelumnya kepada pemegang hak yang lain. Ocean grabbing terjadi melalui proses tata kelola yang tidak tepat dan menggunakan tindakan yang membawa gangguan pada kesejahteraan sosialekologis oleh lembaga negara ataupun pemodal (Bennett, Govan, \& Satterfield, 2015: 63-65). Bennett, Govan, dan Satterfield (2015: 63-65) telah membuat beberapa kriteria yang dapat digunakan untuk melihat apakah proses ocean grabbing sedang berlangsung, yakni kualitas pemerintahan, adanya tindakan yang merongrong keamanan dan mata pencaharian serta dampak negatif pada kesejahteraan sosio-ekologis.

Pertama, pertimbangan kualitas pemerintahan yang dipahami sebagai struktur, institusi dan proses di mana keputusan dibuat dan diambil melalui otoritas ekonomi, politik dan administrasi. Kualitas tata kelola dianggap baik, apabila kontrak sosial normatif antara negara dengan sektor swasta dan masyarakat sipil dapat dilaksanakan. Kedua, apakah suatu inisiatif pembangunan akan merusak kelompok masyarakat pesisir yang rentan. Apabila pembangunan yang dilakukan mengancam keberlanjutan mata pencaharian masyarakat pesisir berarti nampaklah telah terjadi proses perampasan laut. Ketiga, apakah inisiatif pembangunan membawa dampak negatif secara ekologis dan kesejahteraan komunitas setempat menjadi terganggu. Kesejahteraan memiliki sudut pandang yang beragam meliputi aspek sosial, budaya, kelembagaan, dan ekonomi (Bennett, Govan, \& Satterfield, 2015: 63-65).

Studi yang ada belum mengelaborasi gejala ocean grabbing dalam kasus proyek reklamasi dan masih terbatas pada pertumbuhan ekosistem pesisir di sektor ekstraktif (sumber daya alam). Misalnya Barbesgaard (2016: 5-7) mendalami bagaimana proses overcapitalization yang terjadi dalam industri perikanan. Finansialisasi, teritorialisasi yang dilakukan negara, privatisasi langsung,- dan perikanan tangkap dalam skala besar telah memperparah krisis sosio-ekologis yang terjadi di wilayah perairan laut (Barbesgaard, 2016: 11-13).

Finansialisasi untuk memfasilitasi ekspansi investasi merupakan pendorong serius kerusakan sosio-ekologis yang terjadi di ekosistem perairan laut. Knott dan Neis (2016: 2-3) juga mendalami komersialisasi perikanan di New Brunswick, Kanada yang memunculkan koneksi antara ekonomi setempat dan skala global yang membawa kerusakan ekosistem laut. Kasus perikanan tangkap salmon yang ada di New Brunswick menghadapi proses finansialisasi besar-besaran akibat masuknya modal global. Proses tersebut menyebabkan hilangnya kontrol komunitas atas sumber daya laut serta terlepasnya ikatan sosio-historis mereka dengan ekosistem setempat (Knott \& Neis, 2016: 6-7).

Teritorialisasi menjadi titik awal untuk memfasilitasi investasi besar sektor perikanan yang menunjukkan terjadinya fenomena ocean grabbing. Teritorialisasi menjadi langkah bagi penentuan otoritas mana yang akan melakukan pengaturan mengenai kontrol, akses, pemanfaatan, distribusi serta penguasaan ruang pesisir dan perairan laut (Foley \& Mather, 2018: 4-6). Banyak kasus menunjukkan bahwa negara lebih sering berpihak pada investasi modal besar sehingga meminggirkan keberadaan komunitas yang memiliki hubungan timbal balik dengan ekosistem perairan laut (Foley \& Mather, 2018: 13-15).

Barbesgaard (2019: 195-196) menggunakan pendekatan lanskap geografis bersama dengan ekonomi-politik untuk memahami bagaimana teritorialisasi berkaitan dengan perubahan moda produksi di pesisir dan perairan laut. Studinya di Myanmar Selatan menemukan bahwa lembaga ekstraksi sumber daya menjadi pihak yang menjadi bagian dari proses perampasan perairan laut dari komunitas setempat. Tren yang berkembang di wilayah pesisir untuk memfasilitasi investasi dalam skala besar terus menggerus moda produksi dan relasi sosial agraria antara komunitas dan ekosistem perairan laut. Perubahan lanskap juga diintervensi pula sesuai dengan moda produksi yang dijalankan di wilayah pesisir (Barbesgaard, 2019: 198-201).

Berbeda dengan kajian sebelumnya, studi ini akan mendalami proyek reklamasi yang menjadi tren ekspansi modal di wilayah pesisir Indonesia dan Malaysia yang justru menggerus sektor perikanan. Finansialisasi, komersialisasi, dan 
teritorialisasi menjadi kunci penting yang akan digunakan untuk memahami proyek reklamasi sebagai bentuk ekspansi modal yang membawa kerusakan secara ekologis dan sosial. Kriteria mengenai ocean grabbing dari Bennett, Govan, \& Satterfield (2015: 63-65) akan membantu memahami proses reklamasi di Indonesia dan Malaysia yang menunjukkan adanya problem serius. Kasus Malaysia dan Indonesia dipilih untuk diperbandingkan karena memiliki kesamaan dalam tren proyek reklamasi untuk peruntukan pengembangan ruang perkotaan dan metode urugan yang digunakan.

\section{Ocean Grabbing di Indonesia dan Malaysia}

Kriteria dari Bennett, Govan, \& Satterfield (2015: 63-65) membantu kita dalam memahami proses ocean grabbing yang terjadi dalam proyek reklamasi yang ada di Indonesia dan Malaysia. Di Indonesia, berbagai proyek reklamasi yang terjadi tren finansialisasi, teritorialisasi, dan komersialisasi menjadi langkah untuk masuknya modal perkotaan melalui proyek reklamasi. Kasus reklamasi skala besar di Jakarta dalam pembuatan 17 pulau baru dengan dalih mengatasi masalah banjir rob dan penurunan muka tanah semata menunjukkan para pejabat yang memfasilitasi investasi. Kerangka kebijakan sebenarnya secara normatif sudah mengatur terkait ketentuan mengenai perlindungan lingkungan laut dan wilayah pesisir, tetapi banyak pejabat dan pelaku bisnis tidak memiliki pandangan mengenai prinsip keberlanjutan (Husin, 2017: 303-304).

Pengadilan sebenarnya sempat membatalkan proyek reklamasi yang ada di salah satu pulau buatan. Proyek reklamasi tersebut dinilai telah menyalahi kebijakan lingkungan berkelanjutan dari aturan nasional dan internasional. Akan tetapi, Menteri Koordinator Bidang Kemaritiman tidak mengindahkan putusan pengadilan dan masukan dari komite bersama proyek reklamasi Jakarta (Husin, 2017: 306-307). Menteri Koordinator Bidang Kemaritiman terus meminta proyek reklamasi Jakarta terus dilanjutkan, karena dianggap tetap menjadi bagian dari agenda pembangunan pemerintah pusat. Keputusan pemerintah pusat untuk melanjutkan proyek reklamasi yang jelas cacat hukum dan merugikan komunitas serta lingkungan (Husin, 2017: 306307).

Kualitas tata kelola yang buruk juga terdapat dalam megaproyek reklamasi di Teluk Benoa, Bali. Masalah proyek di Teluk Benoa justru lebih parah disebabkan terjadi konflik diagonal di antara berbagai pemangku kepentingan (Wibawa, 2017). Kebijakan menjadi alat paksaan untuk mendorong proyek reklamasi di Teluk Benoa. Pemerintah pusat secara bertahap merubah status kawasan lindung Teluk Benoa menjadi daerah budi daya untuk peruntukan ekonomi. Padahal kebijakan yang lain melarang adanya proses perubahan status kawasan lindung di Teluk Benoa tersebut (Wibawa, 2017).

Pemerintah daerah di Bali juga menghadapi tafsir yang saling bertabrakan dalam megaproyek reklamasi di Teluk Benoa. Kebijakan pemerintah daerah yang sudah ada sebenarnya mempertahankan Teluk Benoa sebagai kawasan lindung, tetapi gubernur baru justru mendorong proyek untuk dilakukan (Wibawa, 2017: 746). Aspirasi dari masyarakat Bali yang menolak dengan alasan merusak ikatan secara ekologis dan religius proyek reklamasi juga tidak didengarkan.

Gubernur Bali yang baru menjabat memaksa pelaksanaan reklamasi dengan instrumen eufemisme dan sensorisasi. Menurut Wibawa (2017: 746-747), hal tersebut menjadi bentuk kekerasan simbolik yang dilakukan pihak Gubernur Bali untuk memaksa pelaksanaan proyek reklamasi. Eufemisme dilakukan dalam bentuk kepercayaan, kewajiban, kesetiaan, hadiah, kesopanan, dan kasih sayang. Mekanisme sensorisasi muncul dalam bentuk "kehormatan secara moral" seperti kesucian, kedermawanan, dan lain-lain. Eufemismisasi dan sensorisasi dilakukan untuk memunculkan argumen kebutuhan dan keuntungan ekonomis untuk melegitimasi proyek reklamasi (Wibawa, 2017: 746-747).

Proyek Reklamasi di Teluk Tering, Batam juga memiliki tata kelola yang buruk disebabkan perencanaan yang buruk. Reklamasi di Teluk Tering tidak diikuti dengan proses teritorialisasi yang memadai dalam pra, pelaksanaan, maupun setelah proyek (Rudianto \& Isdianto, 2020: 6667). Kejelasan status tanah dari pulau buatan 
dari hasil proyek reklamasi bermasalah pula. Kepemilikan tanah hasil dari reklamasi secara terbuka dimiliki oleh perusahaan pengembang sebagai pemilik proyek (Rudianto \& Isdianto, 2020: 66-67). Reklamasi lain yang dilakukan di Pantai Bengkong, Batam, bahkan memberikan keleluasaan bagi perusahaan pengembang untuk memangkas bukit. Perusahaan pengembang diberikan wewenang untuk memangkas bukit tanpa adanya mediasi dengan pemangku kepentingan lain termasuk komunitas masyarakat (Priyandes \& Majid, 2009: 26-27).

Perusahaan pengembang menghadapi permasalahan dengan pemangku kepentingan lain dalam proyek reklamasi di Manado. Proyek reklamasi di Manado menghadapkan pada konflik diagonal antara perusahaan pengembang dengan tuan tanah serta developer bersama nelayan lokal. Proyek reklamasi Manado menyebabkan hilangnya kendali komunitas atas wilayah perairan laut pula yang menunjukkan buruknya tata kelola (Arsyad, 2008: 428).

Konflik kepentingan muncul pula dalam reklamasi di ruas jalan Donggala-Palu dan Pantai Talise. Konflik kepentingan muncul seiring ekspansi investasi yang dilakukan perusahaan pengembang yang membawa persinggungan dengan pemerintah daerah dan komunitas masyarakat (Pawitro, 2015: 151-152). Teritorialisasi di Palu muncul dalam bentuk penetapan daerah sebagai kawasan perekonomian dengan dalih memfasilitasi reklamasi.

Teritorialisasi untuk menetapkan satu wilayah sebagai bagian dari proyek reklamasi sering tidak diikuti regulasi yang memadai pula secara normatif. Proyek reklamasi di Serang, Banten dilakukan atas desakan perusahaan pengembang untuk memfasilitasi ekspansi wilayah industrinya. Reklamasi di Serang Banten tidak diikuti dengan pembentukan Rencana Detail Tata Ruang (RDTR) serta menggerus ekosistem mangrove (Liyubayina, 2018: 41-43).

Di Kabupaten Bangkalan dan Pamekasan bahkan reklamasi terjadi tanpa melalui proses teritorialisasi. Perusahaan pengembang dan masyarakat melakukan reklamasi tanpa melalui pengajuan izin kepada pemerintah disebabkan mereka membutuhkan tambahan lahan (Yulianti, Ikhwan, \& Zaman, 2015: 108-109). Perusahaan pengembang bahkan sering kali membeli tanah yang sudah direklamasi terlebih dahulu oleh warga untuk mendapatkan lahan. Izin reklamasi mudah didapat dengan adanya persetujuan dari pemerintah desa, tetapi menyebabkan proses sertifikasi dan pengaturan status kepemilikan lahan baru menjadi membingungkan (Yulianti, Ikhwan, \& Zaman, 2015: 108-109).

Reklamasi di Kelurahan Gamalama, Kota Ternate juga dilakukan sebelum teritorialisasi dilakukan oleh pemerintah daerah. Perusahaan pengembang dan masyarakat lebih dahulu melakukan reklamasi sebelum ada izin dari pemerintah daerah. Izin reklamasi baru keluar setelah proyek berlangsung, meskipun tidak diikuti dengan proses pengaturan ruang. 97,6\% proyek reklamasi dilakukan oleh perusahaan pengembang di Kota Ternate (Djainal, 2012: 5-7).

Teritorialisasi juga tidak dilakukan dalam proyek reklamasi di Makassar, Sulawesi Selatan dengan dikeluarkannya izin sepihak oleh pemerintah provinsi. Proyek reklamasi yang sebagian pendanaannya ditopang oleh APBD Provinsi Sulawesi Selatan diserahkan pada perusahaan pengembang tanpa adanya peraturan daerah mengenai wilayah pesisir (Aspan, 2017: 174-175). Proyek reklamasi yang sempat dihentikan oleh pihak DPRD kenyataannya terus dilanjutkan untuk memfasilitasi pengembangan properti yang dilakukan pengembang.

Tata kelola yang buruk dalam proses reklamasi di Malaysia menunjukkan adanya dominasi peran elite ekonomi dalam pelaksanaan proyek reklamasi. Elite ekonomi yang memiliki keuangan kuat memiliki kekuasaan dalam membuat proyek reklamasi untuk keperluan bisnis properti. Perkembangan kota pesisir dimanfaatkan menjadi pengembangan investasi yang berusaha mereka perebutkan. Peran serta negara yang besar dalam memfasilitasi reklamasi di Malaysia terjadi disebabkan pemerintah berusaha membentuk bank tanah untuk investasi. Pengembangan lahan yang meluas di perairan laut menjadi bentuk ekspansi modal dari para investor (Meadows, Sengupta, \& Chen, 2018: 230-231). Akan tetapi, tata kelola yang buruk juga muncul dalam reklamasi di Malaysia. Hal tersebut menunjukkan berlakunya kriteria pertama dari 
Bennet yang memperlihatkan adanya problem ocean grabbing akibat reklamasi di Malaysia.

Perencanaan kota di Malaysia menjadi salah satu pilar penting dari perkembangan akumulasi modal melalui proyek reklamasi. Pilar lain yakni modal dan pekerja menjadi pendukung penting pula dalam memfasilitasi masuknya investasi perkotaan yang semakin berkembang ke wilayah pesisir. Perencanaan kota sengaja melihat tanah sebagai komoditas yang berada dalam keadaan langka sehingga apabila ada tambahan kebutuhan pasar akan dilakukan penambahan jumlah lahan (Kumar, 2011: 14-20). Perencanaan kota juga menjadi jalan untuk memastikan skema investasi melalui proyek reklamasi didukung dengan teritorialisasi ruang beserta dengan penyediaan pekerja yang dilibatkan.

Proyek reklamasi yang ada di Malaysia memiliki partisipasi publik yang terbatas. Masyarakat pesisir hanya akan menjadi tenaga kerja yang mengisi proyek pembangunan pariwisata yang dilakukan oleh investor. Partisipasi publik terbatas dengan mengundang pemimpin komunitas yang dianggap mewakili kelompok masyarakat pesisir. Pemimpin komunitas yang ditunjuk sebagai wakil dipandang akan memberikan pemahaman mengenai isu-isu yang berkaitan dengan proyek reklamasi dari sudut pandang pemerintah dan pengembang (Nadzir, Ibrahim, \& Mansor, 2014: 161-162). Akan tetapi, cara tersebut sebenarnya semata langkah pendisiplinan yang dilakukan untuk menghindari konflik dalam proyek reklamasi. Masyarakat pesisir hanya menjadi pihak yang akan menjadi objek rekayasa sosial dalam proyek reklamasi. Akibatnya proyek reklamasi hanyalah menjadi pembangunan pariwisata yang "pasif" (Nadzir, Ibrahim, \& Mansor, 2014: 161-162).

Malaysia juga belum memiliki kebijakan pesisir yang memadai untuk mengatasi erosi dan kerusakan lingkungan yang muncul akibat reklamasi. Kontrol negara atas proyek reklamasi terkesan lemah. Reklamasi yang menciptakan tanah untuk keperluan ekspansi ekonomi berkembang tanpa kendali yang memadai. Kebijakan zonasi pesisir masih dalam proses penyusunan untuk mengendalikan meluasnya proyek reklamasi. Meskipun, realitas menunjukkan justru reklamasi pantai terus terjadi secara masif (Ghazali, 2006: 238-239).

Kegiatan reklamasi yang dilakukan di Penang misalnya, menunjukkan ambisi negara dalam membentuk bank tanah untuk keperluan investasi. Negara mengabaikan kemungkinan kerugian dan kerusakan lingkungan yang akan diderita masyarakat pesisir. Pemerintah Malaysia lebih memilih untuk memuluskan proyek. Pemerintah Malaysia bahkan mengabaikan dampak sosial-ekonomi dan budaya yang muncul dari adanya proyek reklamasi (Chan, 1998: 313-316). Dengan demikian, kontrak sosial normatif yang terjadi antara pemerintah dan masyarakat tidak berjalan baik akibat proyek reklamasi yang menguntungkan kalangan investor semata. Banyak pengembang bahkan berusaha menghindari ketentuan analisis dampak lingkungan dalam pengambilan pasir untuk keperluan menguruk laut. Analisis dampak lingkungan sebenarnya ada untuk melakukan konservasi terhadap hutan dan bukit yang ada di Penang yang belum dirusak untuk keperluan reklamasi (Chan, 1998: 313-316).

Proyek reklamasi yang dilakukan di Batu Pahat dan Pasir Gudang semenjak akhir tahun 90-an juga menunjukkan betapa buruknya proses tata kelola. Dewan kota justru terus menambah lahan untuk proyek reklamasi untuk mengatasi problem abrasi dan banjir akibat pembangunan sebelumnya. Pembangunan kota makin tidak tertata disebabkan ekspansi modal yang difasilitasi di daerah pesisir dengan mudah diberi banyak ruang baru. Modal yang menjadi biang keladi erosi yang terus terjadi justru menambah langkah dewan kota untuk melakukan proyek reklamasi terus-menerus (Rosli, Ahmad, Kaamin, \& Izhar, 2016: 3-5).

Reklamasi yang dilakukan di Pengerang, Kota Tinggi juga menunjukkan adanya tata kelola yang buruk akibat diabaikannya perencanaan secara matang. Meskipun mayoritas warga tidak percaya bahwa proyek reklamasi dilakukan untuk mencukupi kekurangan lahan, mereka percaya bahwa reklamasi akan memberikan dampak pertumbuhan ekonomi. Studi yang dilakukan oleh Sandirasegaran dan Manap (2016: 141-142) menunjukkan bahwa pemangku kepentingan cenderung mengabaikan kesejahteraan masya- 
rakat. Pembangunan reklamasi dilakukan tanpa perencanaan yang baik sebelum proses konstruksi. Pemerintah dan pengembang juga tidak memiliki data teknis yang memadai sebelum melakukan reklamasi di Pengerang (Sandirasegaran \& Manap, 2016: 141-142).

Proyek reklamasi yang dilakukan di Malaka Tengah berjalan dengan kendali yang buruk disebabkan rencana pembangunan telah jatuh tempo. Setiap proyek reklamasi yang akan dilaksanakan harus menyesuaikan dengan perencanaan ruang pesisir setempat, tetapi pengaturan wilayah di Malaka Tengah hanya berlaku sampai tahun 2015. Proyek reklamasi berjalan begitu saja dengan pemberian izin dari pemerintah setempat (Ishak et al., 2016: 4-5).

Proyek reklamasi dengan problem yang mengkhawatirkan juga muncul di Johor. Megaproyek forest city yang dilakukan di Johor memfasilitasi privatisasi skala besar dalam proyek reklamasi. Daratan baru yang dibuat di Johor diklaim oleh pemerintah lokal sebatas pemberian hak sewa, tetapi kenyataannya hak milik (Moser, 2018: 938-939). Proyek forest city akan memberikan visa tetap bagi warga negara asing yang ingin menetap. Dari kalangan elite Malaysia sendiri seperti mantan Perdana Menteri Mahathir Mohamad menyebut proyek tersebut akan mengancam kedaulatan negara. Proyek forest city memungkinkan polisi swasta yang akan mengontrol daratan baru hasil reklamasi bukan aparat keamanan negara. Proyek tersebut menunjukkan bagaimana keberpihakan yang kuat dari negara terhadap investor asing dan tidak mendengarkan kritik publik (Moser, 2018: 938-939). Lebih lanjut perbandingan tata kelola proyek reklamasi di Indonesia dan Malaysia adalah sebagai berikut:

Tabel 1.

Perbandingan Aspek Tata Kelola Proyek Reklamasi di Indonesia dan Malaysia

\begin{tabular}{lll}
\hline \multicolumn{1}{c}{\begin{tabular}{c}
\multicolumn{1}{c}{ Aspek dari } \\
Tata Kelola
\end{tabular}} & \multicolumn{1}{c}{ Indonesia } & \multicolumn{1}{c}{ Malaysia } \\
\hline $\begin{array}{l}\text { Kontrak Sosial dalam } \\
\text { Proyek Reklamasi }\end{array}$ & $\begin{array}{l}\text { Proyek dilaksanakan oleh beragam } \\
\text { pemangku kepentingan sesuai lokasi. Di } \\
\text { Bangkalan dan Ternate, masyarakat ikut } \\
\text { melaksanakan reklamasi mandiri, sedangkan } \\
\text { di tempat lain proyek dilaksanakan untuk } \\
\text { kepentingan investasi. }\end{array}$ & $\begin{array}{l}\text { Proyek difasilitasi oleh negara untuk } \\
\text { kepentingan investasi. }\end{array}$ \\
\hline Partisipasi Publik & $\begin{array}{l}\text { Banyak konflik kepentingan disesuaikan } \\
\text { dengan konteks dari proyek reklamasi di satu } \\
\text { lokasi. }\end{array}$ & $\begin{array}{l}\text { Masyarakat pesisir tidak dilibatkan dalam } \\
\text { pembangunan proyek reklamasi. }\end{array}$ \\
\hline Proses Eksekusi Proyek & $\begin{array}{l}\text { Tumpang tindih perizinan dan kebijakan } \\
\text { terjadi dalam upaya mendukung proyek. }\end{array}$ & $\begin{array}{l}\text { Perencanaan pembangunan yang dibuat oleh } \\
\text { pemerintah tidak matang. }\end{array}$ \\
\hline
\end{tabular}

Sumber: Disarikan dari Berbagai Sumber

Kriteria yang kedua dari Bennett, Govan, \& Satterfield (2015: 63-65) mengenai gangguan terhadap mata pencaharian dan kesejahteraan komunitas masyarakat pesisir menjadi terganggu. Kehidupan perekonomian masyarakat pesisir sudah tergerus oleh kepentingan ekonomi dari perusahaan pengembang yang ingin terus memerlukan ruang baru untuk memfasilitasi ekspansi modalnya (Koto, 2017: 9-10). Reklamasi menjadi jalan bagi negara untuk memfasilitasi perusahaan pengembang yang terus membutuhkan ruang baru. Sifat predatoris dari perusahaan pengembang dalam memangsa ruang perairan laut menunjukkan bagaimana modal meminggirkan realitas wilayah pesisir dan daratan (Koto, 2017: 9-10).

Sifat predatoris pasar telah memicu kenaikan harga tanah secara signifikan di wilayah sekitar proyekreklamasi.Permintaanbesarterhadaptanah untuk keperluan pembangunan pusat bisnis pasca proyek reklamasi memicu kenaikan harga lahan (Hasani, 2015: 30-35). Pengembang lain merasa ingin mendapatkan keuntungan dari proyek pusat kegiatan bisnis baru yang berkembang akibat proyek reklamasi. Akan tetapi, akibat kenaikan harga tanah justru menyebabkan penduduk lokal 
kehilangan lahannya dan terpaksa menjualnya. Akhirnya, mereka pun semakin tercerabut dari ruang hidupnya (Hasani, 2015: 30-35).

Proses deregulasi dan privatisasi sumber daya biasa dilakukan dalam fasilitasi ekspansi modal. Privatisasi dan deregulasi menjadi jalan untuk mengalihkan barang publik menjadi private goods yang akan dikelola oleh swasta. Pengalihan barang publik dilakukan melalui pengaturan ulang dan pemetaan ruang untuk melakukan klaim kepemilikan (Jou, Hansen, \& $\mathrm{Wu}, 2012$ : 156-158). Proyek reklamasi yang dilakukan di Indonesia juga dilakukan dengan proses pengalihan barang publik tersebut, tetapi ada juga pembangunan yang berjalan tanpa memiliki kejelasan status kepemilikan.

Reklamasi di Indonesia dilakukan hanya dengan penekanan pada penilaian "dampak lingkungan" tanpa melihatnya sebagai satu kesatuan dengan implikasi secara sosial-ekonomi dan politik. Dampak serius dari reklamasi secara sosial-budaya, ekonomi, dan politik tidak pernah diperhitungkan secara serius dalam pelaksanaan proyek. Kasus reklamasi untuk keperluan pembangunan Bali Turtle Island Development (BTID) menyebabkan munculnya pelanggaran hak asasi manusia dalam bentuk pengusiran komunitas warga secara paksa, segregasi sosial, gangguan terhadap rumah peribadatan, dan pencerabutan nilai sosial-budaya (Arsyad, 2008: 428). Proyek BTID telah menyebabkan hilangnya mata pencaharian warga pula yang bergantung pada sektor agraris. Pengutamaan kepentingan bisnis dibandingkan kebutuhan warga menyebabkan komunitas selalu dikalahkan (Arsyad, 2008: 428).

Megaproyek reklamasi yang dilakukan di Teluk Benoa, Bali menunjukkan adanya gejala yang lebih mengkhawatirkan disebabkan investor memakai strategi "modernisasi ekologis" untuk memuluskan pembangunannya. Investor yang melihat potensi pasar yang besar dari pariwisata di Bali menangkap adanya keuntungan besar yang akan didapat dari pembangunan resort di Teluk Benoa (Wiranata, Mardliyah, \& Achmad, 2016: 294-296). Investor berdalih pula akan menyelesaikan problem sampah sekitar hutan bakau dan menyelesaikan abrasi di Pulau Pudut dengan "teknologi canggih" untuk menunjukkan "komitmen lingkungan" dari proyek reklamasi. "Teknologi canggih" yang mampu "memulihkan lingkungan" dijanjikan akan membawa "pertumbuhan ekonomi" di Teluk Benoa. Akan tetapi, tetap saja investor akan menjadi pihak yang menguasai dan mengendalikan proyek di Teluk Benoa (Wiranata, Mardliyah, \& Achmad, 2016: 294-296).

Megaproyek reklamasi di Manado memunculkan kondisi perampasan lahan yang lebih kompleks disebabkan adanya konflik diagonal antara nelayan-pengembang dan developer-tuan tanah. Penguasaan pengembang atas daerah tangkapan ikan dan area penahan kapal mereka. Proyek reklamasi telah menutup akses masyarakat pesisir atas pantai dan melanggar hak komunal atas wilayahnya pula (Arsyad, 2008: 428).

Proyek reklamasi di Jakarta menunjukkan bagaimana pengaruh investor dari Belanda dalam mengatur perencanaan tata kota. Reklamasi di Teluk Jakarta dilakukan untuk memfasilitasi ketertarikan pengusaha-pengusaha dari Belanda akan potensi pasar properti yang berkembang (Colven, 2017: 251-253). Proyek reklamasi juga diklaim oleh pemerintah dan investor akan mensubsidi pengatasan problem banjir di Jakarta. Akan tetapi, peran yang sangat kuat dari pengusaha dan pemerintah Belanda dalam mendikte berbagai proyek dalam pengembangan wilayah reklamasi sebagai kawasan perekonomian cukup kental (Colven, 2017: 251-253).

Reklamasi dilakukan dengan sudut pandang pemerintah dan pengusaha Belanda yang menangkap pengembangan wilayah utara Jakarta sebagai lokasi pasar properti yang besar. Investasi dari Belanda dalam proyek reklamasi bahkan mendikte untuk menggeser central business district (CBD) Jakarta ke bagian utara wilayah tersebut. Pemerintah dan pengusaha Belanda yang membiayai proyek reklamasi dengan mudahnya merebut kontrol dan penguasaan atas wilayah Teluk Jakarta untuk kepentingan bisnisnya (Colven, 2017: 251-253). Akibat penguasaan oleh investor tersebut nelayan di Teluk Jakarta kehilangan daerah tangkapan ikannya dan harus mencari wilayah lebih jauh. Kebanyakan dari mereka bahkan harus meninggalkan tempat 
tinggalnya akibat terdampak reklamasi. Proyek reklamasi di Jakarta telah menyingkirkan kelompok marginal, tetapi justru berusaha memindahkan kelas menengah atas ke CBD yang baru.

Reklamasi di Teluk Tering di Batam, Kepulauan Riau berada dalam kondisi yang lebih mengkhawatirkan disebabkan murni dilakukan untuk fasilitasi perluasan kawasan ekonomi. Permintaan pengusaha untuk memperluas wilayah produksinya dengan mudah direspons oleh pemerintah daerah. Meskipun perencanaan ruang belum ada, proyek reklamasi tetap berjalan (Rudianto \& Isdianto, 2020: 60-62). Proyek reklamasi di Teluk Tering memunculkan problem kepemilikan lahan baru dan membatasi akses masyarakat pesisir terhadap sumber daya kelautan. Proyek reklamasi membawa dampak buruk bagi masyarakat pesisir yang harus bersusah payah untuk mendapatkan tangkapan ikan. Sedimentasi yang muncul dari reklamasi bahkan memaksa warga harus meninggalkan kampung halamannya untuk mencari tempat penghidupan baru (Rudianto \& Isdianto, 2020: 60-62).

Di Malaysia, efek yang ditimbulkan dari proyek reklamasi dalam peminggiran kehidupan masyarakat pesisir lebih besar disebabkan adanya pengabaian negara terhadap aspek sosialekonomi dan budaya yang ditimbulkannya. Pengalihan yang dilakukan oleh pemerintah Malaysia dari perekonomian berbasis masyarakat lokal menjadi industri pariwisata/properti untuk menciptakan konsumsi massal telah mendorong krisis sosial dan ekologis secara bersamaan (Doerr, 2016: 8-12).

Proyek reklamasi yang dilakukan di Penang benar-benar telah mengancam rantai ekonomi dan makanan yang ada di pesisir. Mata pencaharian nelayan terancam mendapatkan pendapatan yang menurun. Nelayan di Penang bahkan harus meningkatkan investasi untuk membeli alat tangkap baru menyesuaikan dengan daerah tangkapan ikan yang makin jauh dari area sebelumnya (Sahabat Alam Malaysia, 2019: 5-9). Kompensasi yang diberikan dalam proyek reklamasi kenyataannya tidak cukup untuk menutupi kerugian yang harus ditanggung para nelayan. Rute penangkapan ikan yang lebih jauh menambah biaya bahan bakar tambahan yang harus ditanggung sendiri oleh nelayan pula. Penjualan pasir secara ilegal oleh oknum penduduk untuk keperluan menambah daratan dalam proyek reklamasi di Penang juga rentan memunculkan gesekan tersendiri di antara kelompok warga. Masyarakat pesisir di Penang minim mendapatkan dampak kesejahteraan dari reklamasi disebabkan proses konstruksi lebih banyak melibatkan pekerja asing pula. Akibatnya, terjadilah pemiskinan yang membawa sentimen negatif berbasis etnisitas yang menguat (Sahabat Alam Malaysia, 2019: 5-9).

Di Batu Pahat dan Pasir Gudang, reklamasi menyebabkan urbanisasi terjadi secara tidak terkendali. Peningkatan pesat urbanisasi menyebabkan masyarakat lokal kehilangan jaminannya atas keberadaan properti dan hak komunal mereka (Meadows, Sengupta, \& Chen, 2018: 234-236). Perkembangan resort yang tidak terkendali telah memangsa ruangruang pesisir dan mencipta wilayah baru untuk keperluan pembangunan properti yang makin meluas pula. Peningkatan jumlah lahan tandus makin bertambah banyak pasca pelaksanaan reklamasi sehingga menyebabkan masyarakat lokal kehilangan banyak vegetasi (Meadows, Sengupta, \& Chen, 2018: 234-236).

Reklamasi di Pengerang, Kota Tinggi kehidupan masyarakat pesisir berubah total akibat terjadinya megaproyek. Proyek reklamasi menyebabkan pendapatan masyarakat pesisir menurun. Proyek reklamasi yang tidak diikuti dengan perencanaan memadai cenderung mengabaikan dampak sosial-ekonomi yang diderita masyarakat pesisir (Sandirasegaran \& Manap, 2016: 141-142). Bisnis masyarakat pesisir juga terimbas proyek reklamasi bahkan banyak di antara mereka harus direlokasi ke tempat baru yang disediakan.

Relokasi dari proyek reklamasi di Pengerang menyebabkan kerugian besar dalam jaminan aset tetap dan sementara yang dimiliki masyarakat pesisir. Relokasi menyebabkan masyarakat pesisir kesulitan pula mencari mata pencaharian 
baru disebabkan keterbatasan jenjang pendidikan mereka. Derita masyarakat pesisir semakin bertambah dengan adanya polusi air dan suara serta penurunan jumlah tangkapan ikan (Sandirasegaran \& Manap, 2016: 141-142).

Di Malaka Tengah, ketidakmampuan pemerintah lokal dalam mengatur ruang dalam reklamasi menyebabkan akumulasi masalah yang terjadi. Detail lokasi dan cakupan proyek reklamasi menyebabkan adanya potensi konflik sosial yang terjadi. Ketidakjelasan status dan batas antara lahan reklamasi dan area daratan asli menyebabkan proyek berjalan tanpa arahan yang jelas. Proyek reklamasi juga tidak diikuti dengan perkiraan yang memadai mengenai kapasitas gedung yang dibangun menyesuaikan dengan daya dukung lahan baru (Ishak et al., 2016: 5-6). Rencana pembangunan yang habis tempo pada tahun 2015 menyebabkan pengaturan reklamasi terkesan ad hoc sehingga jaminan terhadap kehidupan masyarakat pesisir yang terdampak kurang diperhatikan.

Proyek forest city di Johor yang berada dalam kendali swasta membawa dampak yang lebih besar bagi penghidupan masyarakat pesisir. Reklamasi telah menyebabkan penurunan pendapatan secara signifikan yang harus dihadapi oleh nelayan. Studi yang dilakukan oleh Jumain, Kamarulzaman, Latif, dan Yusoff (2018: 92-94) telah membuktikan adanya penurunan jumlah pendapatan dan tangkapan ikan akibat proyek reklamasi yang dilakukan. Keberlangsungan mata pencaharian nelayan menjadi terancam akibat pelaksanaan reklamasi. Nelayan memiliki persepsi negatif terhadap proyek reklamasi dan menganggap bahwa penurunan jumlah tangkapan terpengaruh oleh perusakan ekosistem perairan laut (Jumain et al., 2018: 92-94).

Forest city juga menjadi praktik dari privatisasi skala luas yang lebih parah daripada kawasan ekonomi khusus. Tingkat otonomi yang tinggi yang diberikan pada swasta terutama investor dari Cina menyebabkan sumber daya benar-benar diprivatisasi secara masif. Proyek forest city dikembangkan dengan dalih meningkatkan hubungan dengan Beijing (Moser, 2018: 940-941). Kendali dari Beijing yang kuat dalam mengendalikan wilayah reklamasi bahkan disesuaikan dengan proyek ambisius mereka untuk menghidupkan kembali jalur perdagangan dan pelayaran di masa lampau.

Cara pemerintah untuk mendorong privatisasi sumber daya yang ada di Malaysia dan berdampak pada kehidupan masyarakat pesisir terutama nelayan dapat dipahami melalui empat langkah (Transnational Institute, 2014: 15-18). Pertama, pembenaran narasi bahwa sumber daya dikelola secara salah urus sehingga dimungkinkan dilakukannya privatisasi dengan alasan akan mendorong perbaikan. Kedua, proses pemetaan secara sepihak wilayah reklamasi yang akan digunakan untuk peruntukan investasi. Ketiga, penegasan kedaulatan dan kekuasaan negara atas pelaksanaan investasi dalam proyek reklamasi. Keempat, alokasi ulang akses dan kontrol atas negara. Negara menjadi broker utama untuk memastikan bahwa investor dapat melaksanakan proyek reklamasi sesuai dengan skema yang mereka inginkan. Cara-cara yang diambil oleh negara untuk memfasilitasi investasi telah menyebabkan kerusakan ekologis serius di wilayah-wilayah yang dilakukan proyek reklamasi demi keuntungan ekonomi.

Semua proyek reklamasi yang ada di Indonesia telah membawa dampak serius bagi kerusakan lingkungan yang makin bertambah parah (Koto, 2017: 14-17). Daratan baru menyebabkan ruang perairan laut tergeser dan menyebabkan keseimbangan lingkungan terganggu sehingga menyebabkan pergeseran garis pantai, penyumbatan muara sungai, pemurnian air terhambat, polusi yang bertambah parah, dan merubah tata air dari sungai ke laut (Koto, 2017: 14-17). Sedimentasi yang bertambah parah juga membawa bencana banjir dan abrasi yang bertambah parah di Jakarta, Batam, Kabupaten Bengkong, Manado, dan daerah lainnya yang terdampak proyek reklamasi. Masyarakat pesisir terus menjadi korban akibat dari kerakusan investor yang sudah mengambil ruang hidup mereka. Berikut adalah gambaran dari krisis sosio-ekologis yang ditimbulkan dari proyek reklamasi di Indonesia dan Malaysia: 
Tabel 2.

Krisis Sosio-Ekologis Akibat Proyek Reklamasi di Beberapa Wilayah Indonesia

\begin{tabular}{|c|c|c|}
\hline No & $\begin{array}{l}\text { Lokasi Proyek } \\
\text { Reklamasi }\end{array}$ & Krisis Sosio-Ekologis yang Muncul \\
\hline 1. & Teluk Jakarta & $\begin{array}{l}\text { Menurunnya salinitas dan kejernihan air; sedimentasi membuat kehidupan } \\
\text { biota laut terancam; menggeser daerah alat tangkapan ikan aktif dan pasif; } \\
\text { mempercepat laju penurunan kelimpahan ikan; terganggunya keseimbangan } \\
\text { ekosistem laut (Puspasari, Hartati, \& Anggawangsa, 2017: 88-92). }\end{array}$ \\
\hline 2. & $\begin{array}{l}\text { Kabupaten Pamekasan } \\
\text { dan Bangkalan, Jawa } \\
\text { Timur }\end{array}$ & $\begin{array}{l}\text { Ketidakjelasan pengaturan status tanah; perluasan garis pantai; terpinggirkannya } \\
\text { kehidupan masyarakat terdampak perluasan tambak (Yulianti, Ikhwan, \& Zaman, } \\
\text { 2015: 112-113). }\end{array}$ \\
\hline 3. & Serang, Banten & $\begin{array}{l}\text { Penurunan tangkapan ikan; rusaknya ekosistem padang lamun, mangrove, dan } \\
\text { terumbu karang; sedimentasi yang makin meningkat (Liyubayina, 2018: 43-44). }\end{array}$ \\
\hline 4. & Manado, Sulawesi Utara & $\begin{array}{l}\text { Perusakan terumbu karang (Doaly, 2019); hilangnya daerah tangkapan ikan } \\
\text { dan tambatan kapal; pergantian profesi nelayan secara masif; pencerabutan } \\
\text { masyarakat pesisir dari ikatan ruang hidup dan identitasnya (Piri, 2020). }\end{array}$ \\
\hline 5. & $\begin{array}{l}\text { Kota Batam, Kepulauan } \\
\text { Riau }\end{array}$ & $\begin{array}{l}\text { Pengurangan jumlah tangkapan ikan; peningkatan jumlah sedimen yang } \\
\text { menyebabkan pengurangan kadar oksigen; sedimen menyebabkan penduduk } \\
\text { pesisir harus dipindah dari ruang hidup (Rudianto \& Isdianto, 2020: 62-63). }\end{array}$ \\
\hline 6. & $\begin{array}{l}\text { Kota Makassar, Sulawesi } \\
\text { Selatan }\end{array}$ & $\begin{array}{l}\text { Penurunan jumlah tangkapan; hilangnya daerah tangkapan ikan; penurunan } \\
\text { jumlah pendapatan (Aspan, 2017: 174-175). }\end{array}$ \\
\hline 7. & $\begin{array}{l}\text { Kota Palu, Sulawesi } \\
\text { Tengah }\end{array}$ & $\begin{array}{l}\text { Kerusakan ekosistem mangrove; penurunan tangkapan ikan; kerusakan terumbu } \\
\text { karang (Pawitro, 2015: 151). }\end{array}$ \\
\hline 8. & $\begin{array}{l}\text { Kelurahan Gamalama, } \\
\text { Kota Ternate }\end{array}$ & $\begin{array}{l}\text { Banjir yang meningkat; sedimentasi bertambah parah; perubahan pasang air laut; } \\
\text { perubahan pola arus (Djainal, 2012: } 8-10 \text { ). }\end{array}$ \\
\hline
\end{tabular}

Sumber: Diolah dari Berbagai Sumber

Tabel 3.

Krisis Sosio-Ekologis Akibat Proyek Reklamasi di Beberapa Wilayah Malaysia

\begin{tabular}{|c|c|c|}
\hline No & $\begin{array}{c}\text { Lokasi Proyek } \\
\text { Reklamasi }\end{array}$ & Krisis Sosio-Ekologis yang Muncul \\
\hline 1. & Penang & $\begin{array}{l}\text { Pemangkasan bukit; Hilangnya daerah tangkapan hujan akibat pengerukan } \\
\text { pasir (Chan, 1998: 306-308); Penumpukan sedimen; Perubahan gelombang } \\
\text { laut; Hilangnya ekosistem bentik laut; Penghancuran zona penyangga; } \\
\text { Ketidakseimbangan rantai makanan; Instrusi air laut ke sistem air tanah; Polusi } \\
\text { air laut (Sahabat Alam Malaysia, 2019: 10-12). }\end{array}$ \\
\hline 2. & $\begin{array}{l}\text { Batu Pahat dan Pasir } \\
\text { Gudang }\end{array}$ & $\begin{array}{l}\text { Erosi pantai; Perubahan fisik garis pantai; Pengurangan jumlah vegetasi; } \\
\text { Penambahan jumlah lahan tandus (Rosli et al., 2016: 7). }\end{array}$ \\
\hline 3. & Pengerang, Kota Tinggi & $\begin{array}{l}\text { Rusaknya habitat; Penurunan jumlah tangkapan ikan; Polusi air laut; Penurunan } \\
\text { kesehatan masyarakat; Penambahan sedimen (Sandirasegaran \& Manap, 2016: } \\
\text { 141-142). }\end{array}$ \\
\hline 4. & Malaka Tengah & $\begin{array}{l}\text { Penurunan jumlah tangkapan ikan; Peningkatan kerusakan kapal nelayan; } \\
\text { Gangguan terhadap pemukiman masyarakat pesisir (Murali \& Mahorm, 2018); } \\
\text { Gangguan terhadap konservasi penyu; Penambahan jumlah sedimen (Mayberry, } \\
\text { 2016). }\end{array}$ \\
\hline 5. & Forest City Johor & $\begin{array}{l}\text { Kerusakan ekosistem padang lamun; Ancaman kehidupan yang dialami spesies } \\
\text { langka seperti duyung, kura-kura hijau, dan lain-lain; Penambahan jumlah sedimen } \\
\text { (Hossain, Hashim, Bujang, Zakaria, \& Muslim, 2018: 20-24); Kerusakan hutan } \\
\text { bakau (Kanniah et al., 2015: 14370-14375). }\end{array}$ \\
\hline
\end{tabular}

Sumber: Diolah dari Berbagai Sumber 


\section{Penutup}

Kajian ini telah menunjukkan adanya fenomena ocean grabbing dalam proyek reklamasi yang terjadi di Indonesia dan Malaysia. Penyakit lapar tanah untuk keperluan investasi properti menjadi penyebab bagi terjadinya krisis sosio-ekologis yang harus diderita oleh masyarakat pesisir di kedua negara. Kriteria yang dibuat oleh Bennet sangat membantu dalam memahami fenomena ocean grabbing yang terjadi dalam kondisi yang parah. Pertama, reklamasi di Indonesia dan Malaysia sama-sama memiliki tata kelola yang buruk. Minimnya partisipasi publik serta perencanaan pembangunan yang memadai menunjukkan bagaimana ekspansi ekonomi tidak difasilitasi melalui kontrak sosial normatif di antara pemangku kepentingan. Proses pelaksanaan proyek yang berjalan secara terselubung di antara pemerintah dan swasta menunjukkan bagaimana pembangunan sekali lagi tidak berpihak pada masyarakat pesisir. Dengan demikian, sekali lagi menunjukkan pengaturan ruang semata digunakan untuk memfasilitasi ekspansi modal.

Kedua, dampak yang ditimbulkannya terhadap mata pencaharian dan kehidupan masyarakat pesisir. Kejadian sama yang harus diderita oleh masyarakat pesisir terdampak proyek reklamasi adalah penurunan jumlah tangkapan ikan, relokasi, pertambahan biaya penangkapan, hilangnya daerah tangkapan dan penambatan kapal, dan penurunan pendapatan. Masyarakat pesisir benar-benar telah tercerabut dari ruang hidup dan identitasnya. Masyarakat pesisir kesulitan untuk menyesuaikan dengan moda produksi ekonomi baru pasca proyek reklamasi yang lebih banyak menguntungkan investor. Ketiga, krisis sosio-ekologis yang terjadi juga menyebabkan kondisi lingkungan semakin rusak sehingga keseimbangan ekosistem dan perkembangan ruang perkotaaan tidak terkendali. Penambahan jumlah sedimen dan erosi pantai menjadi biang keladi dari meningkatnya abrasi dan banjir yang harus diderita pula oleh masyarakat pesisir terdampak proyek reklamasi di kedua negara. Penambahan jumlah sedimen juga telah merusak siklus air dari hulu-hilir, meningkatkan polusi, bahkan mengubah keseimbangan ekosistem perairan laut.
Pengaturan ruang pesisir dengan melibatkan masyarakat pesisir perlu dilakukan untuk mencegah kembali meluasnya fasilitasi proyek reklamasi untuk keperluan ekspansi modal. Kebijakan pengaturan ruang pesisir perlu terintegrasi dengan pengetahuan lokal dalam memanfaatkan area sesuai dengan ikatan identitas dan pemanfaatannya. Masyarakat pesisir adalah pihak yang paling mengerti mengenai kondisi lingkungan setempat serta pemanfaatan dan pengelolaan sesuai dengan kondisi fisiknya. Pengaturan ruang pesisir memang perlu melibatkan masyarakat pesisir yang selama ini telah merawat dan menjaga ekosistem setempat.

\section{Daftar Pustaka}

Abdullah', D. I. H. S. bin, \& Loi, H. K. (1992). Coastal Reclamation In Malaysia. In Regional Seminar on Land Reclamation for Urban Development. University Malaya, Kuala Lumpur, August 10 11, 1992, 1-11.

Amanda, A., Ngenget, I., \& Makhdor, M. (2019). Kebijakan Gubernur Basuki Tjahaja Purnama dalam Reklamasi Pantai Utara Tahun 20142017. Jurnal ISIP: Jurnal Ilmu Sosial dan Ilmu Politik, 16(2), 105-118.

Ambari, M. (2019, September 18). Reklamasi Pesisir Jadi Pilihan Rakyat atau Pemerintah? Retrieved from https://www.mongabay.co.id/2019/09/18/ reklamasi-pesisir-jadi-pilihan-rakyat-ataupemerintah/, on February 25, 2020.

Arsyad, A. (2008). Coastal reclamation projects in Indonesia: the weaknesses which lead to severe socio-environmental impacts. In International Conference on Environmental Research and Technology. Universiti Sains Malaysia, Penang, May 28-30, 2008, 426-429.

Aspan, Z. (2017). Tinjauan Yuridis Izin Reklamasi Pantai Makassar Dalam Mega Proyek Centre Point Of Indonesia. Bina Hukum Lingkungan, 1(2), 172-189. doi: 10.24970/jbhl.v1n2.14.

Barbesgaard, M. (2016). Blue growth: saviour or ocean grabbing? In Global governance/politics, climate justice \& agrarian/social justice: linkages and challenges An international colloquium. International Institute of Social Studies, The Hague, February 4-5, 2016, 1-16. 
Barbesgaard, M. (2019). Ocean and land controlgrabbing: The political economy of landscape transformation in Northern Tanintharyi, Myanmar.Journal ofRural Studies, 69(July 2018), 195-203. doi: 10.1016/j.jrurstud.2019.01.014.

Bennett, N. J., Govan, H., \& Satterfield, T. (2015). Ocean grabbing. Marine Policy, 57(1), 61-68.

Chan, N. W. (1998). Environmental hazards associated with hill land development in Penang Island, Malaysia: some recommendations on effective management. Disaster Prevention and Management, 7(4), 305-318.

Colven, E. (2017). Understanding the Allure of Big Infrastructure: Jakarta's Great Garuda Sea Wall Project. Water Alternatives, 10(2), 250-264.

Djainal, H. (2012). Reklamasi Pantai Dan Pengaruhnya Terhadap Lingkungan Fisik Di Wilayah Kepesisiran Kota Ternate. Jurnal Lingkungan Sultan Agung, 1(1), 1-13.

Doaly, T. (2019, January 20). Begini Dampak Merusak Reklamasi Pantai Malalayang Dua Manado. Retrieved from https://www.mongabay. co.id/2019/01/20/begini-dampak-merusakreklamasi-pantai-malalayang-dua-manado/, on March 15, 2020.

Doerr, F. (2016). Blue Growth and Ocean Grabbing: A Historical Materialist Perspective on Fisheries in East Africa. In Global governance/politics, climatejustice \& agrarian/social justice: linkages and challenges. An international colloquium. International Institute of Social Studies, The Hague, February 4-5, 2016, 1-20.

Foley, P. \& Mather, C. (2018). Ocean grabbing, terraqueous territoriality and social development. Territory, Politics, Governance, (1), 1-18.

Ghazali, N. H. M. (2006). Aquatic Ecosystem Health $\&$ Management Coastal erosion and reclamation in Coastal erosion and reclamation. Malaysia. Aquatic Ecosystem Health \& Management, 9(2), 37-41. doi: 10.1080/14634980600721474.

Grydehøj, A. (2015). Making Ground, Losing Space: Land Reclamation and Urban Public Space in Island Cities. Urban Island Studies, 1(December), 96-117. doi: 10.20958/uis.2015.6.

Hasani, M. F. (2015). Kajian Dampak Sosial Ekonomi Pengembangan Reklamasi Pantai Untuk Kawasan Ruang Publik (Studi Kasus: Pantai Losari, Makassar). Laporan Penelitian. Pusat Penelitian dan Pengembangan Sosial, Ekonomi, dan Lingkungan Badan Penelitian dan
Pengembangan Pekerjaan Umum Kementerian Pekerjaan Umum.

Himawan, A. \& Tolen, N. (2016). Total Ada 37 Proyek Reklamasi di Indonesia. Suara. com. Retrieved from https://www.suara.com/ bisnis/2016/10/04/183704/total-ada-37-proyekreklamasi-di-indonesia, on February 25, 2020.

Hossain, M. S., Hashim, M., Bujang, J. S., Zakaria, M. H., \& Muslim, A. M. (2018). Assessment of the impact of coastal reclamation activities on seagrass meadows in Sungai Pulai estuary, Malaysia, using Landsat data (1994-2017). International Journal of Remote Sensing, 1-34.

Husin, S. (2017). Reclamation In The View Of The Protection Of Marine Environment Under The Environmental Law And The Law Concerning The Management Of Based On The Pro And Con Statements Mentioned Above, It Is Obvious That The Role Of Laws And Regulation Is Inevitables. Indonesian Journal of International Law, 14(3), 309-320. doi: 10.17304/ijil.vol14.3.698.

Ishak, N. S., Yusup, M., Arshad, A. F., \& Abdullah, Y. A. (2016). A Review on the Significance of Local Plan for Coastal Reclamation Development: The Case of Malacca, Malaysia. In MATEC Web of Conferences 66. Kuala Lumpur, March 7-8, 2016, 1-8.

Jou, S., Hansen, A. L., \& Wu, H. (2012). Accumulation by Dispossession and Neoliberal Urban Planning: 'Landing' the Mega-Projects in Taipei. In T. Tasan-Kok \& G. Baeten (Eds.), Contradictions of Neoliberal Planning Cities, Policies, and Politics, 151-171. New York: Springer-Verlag Berlin Heidelberg. doi: 10.1007/978-90-4818924-3.

Jumain, N. A., Kamarulzaman, N. H., Latif, I. A., \& Yusoff, F. M. (2018). Impact of Reclamation on Fishery Activities in Malaysia. International Journal of Agriculture, Environment and Bioresearch, 3(3), 87-97.

Kalalo, F. P. (2009). Kebijakan Reklamasi Pantai dan Laut: Implikasi terhadap Hak Masyarakat Pesisir dan Upaya Perlindungannya. Jurnal Hukum dan Pembangunan, 39(1), 102-118.

Kanniah, K. D., Sheikhi, A., Cracknell, A. P., Goh, H. C., Tan, K. P., Ho, C. S., \& Rasli, F. N. (2015). Satellite Images for Monitoring Mangrove Cover Changes in a Fast Growing Economic Region in Southern Peninsular Malaysia. Remote Sens, 7, 14360-14385. 
Knott, C. \& Neis, B. (2016). Privatization, financialization, and ocean grabbing in New Brunswick herring fisheries and salmon aquaculture. Marine Policy, 80(1), 1-9.

Koto, J. (2017). Preliminary Study on Impacts of Reclamation of 17 Islands in Jakarta Bay Preliminary Study on Impacts of Reclamation of 17 Islands in Jakarta Bay. International Journal of Environmental Research \& Clean Energy, 8(1), 9-17.

Kumar, A. (2011). Land in the Neoliberal Times: A Commodity or a Social Good? India Journal, 8(2), 8-23.

Liyubayina, V. (2018). Analisis Dampak Reklamasi Teluk Banten (Studi Kasus: Kecamatan Bojonegara). Jurnal Planesa, 9(1), 37-46.

Mahdi, I. (2017). Reklamasi Teluk Jakarta; Sebuah Perspektif Kekuasaan dalam Ekonomi Politik. Jurnal Transformasi Global, 4(1), 38-45.

Maulidiyah, I. (2016). Perizinan Reklamasi Pantai Dalam Kaitannya dengan Perlindungan dan Pengelolaan Lingkungan Hidup di Kota Bandar Lampung. Tesis. Program Studi Magister Ilmu Hukum Fakultas Hukum Universitas Lampung.

Mayberry, K. (2016, December 2). Land reclamation in Malaysia puts environment, endangered turtle at risk. Retrieved from https://news.mongabay. com/2016/12/land-reclamation-in-malaysiaputs-environment-endangered-turtle-at-risk/, on February 25, 2020.

Meadows, M. E., Sengupta, D., \& Chen, R. (2018). Building beyond land: An overview of coastal land reclamation in 16 global megacities. Applied Geography, 90(December), 229-238. doi: 10.1016/j.apgeog.2017.12.015.

Mohamed, J. \& Razman, M. R. (2018). Management And Initiatives Towards Sustainable Coastal Development In Malaysia: Experience From Reclamation Activities In Malacca. Asian Journal of Environment, History and Heritage, 2(1), 23-32.

Moser, S. (2018). Forest City, Malaysia, and Chinese Expansionism. Urban Geography, 39(6), 935943.

Murali, R. S. N. \& Mahorm, S. (2018, September 18). Melaka looking for loopholes to stop reclamation project. Thestar.com. Retrieved from https:// www.thestar.com.my/news/nation/2018/09/18/ melaka-looking-for-loopholes-to-stopreclamation-project/, on March 16, 2020.
Nadzir, N. M., Ibrahim, M., \& Mansor, M. (2014). Impacts of Coastal Reclamation to the Quality of Life: Tanjung Tokong community, Penang. Procedia - Social and Behavioral Sciences, 153, 159-168. doi: 10.1016/j.sbspro.2014.10.050.

Pawitro, U. (2015). Reklamasi Kawasan Pesisir Pantai: antara Pelestarian Lingkungan dan Ekonomi Kawasan. In Prosiding Temu Ilmiah IPLBI 2015. Universitas Sam Ratulangi, Manado, October 30-31, 2015, 147-154.

Piri, I. E. (2020, January 11). Terpinggir karena Reklamasi, Nasib Nelayan Teluk Manado Kini [2]. Retrieved from https://www.mongabay. co.id/2020/01/11/terpinggir-karena-reklamasinasib-nelayan-teluk-manado-kini-2/, on March $15,2020$.

Priyandes, A. \& Majid, M. R. (2009). Impact of Reclamation Activities on the Environment Case Study: Reclamation in Northern Coast of Batam. Jurnal Alam Bina, 15(1), 1-14.

Puspasari, R., Hartati, S. T., \& Anggawangsa, R. F. (2017). Analisis Dampak Reklamasi terhadap Lingkungan dan Perikanan di Teluk Jakarta. Jurnal Kebijakan Perikanan Indonesia, 9(2), 85-94.

Rosli, M. I., Ahmad, M. A., Kaamin, M., \& Izhar, M. F. N. (2016). Shoreline Delineation and Land Reclamation Change Detection Using Landsat Image. In IOP Conference Series: Materials Science and Engineering. Langkawi, October 27-29, 2015, 1-9.

Rudianto \& Isdianto, A. (2020). Management of Sustainable Coastal Reclamation Areas: A Case Study of the Reclamation of Tering Bay in Batam Island, Indonesia. Journal of Aquaculture and Fish Health, 9(February), 57-68.

Ruslin, I. T. (2017). Subaltern dan Kebijakan Pembangunan Reklamasi Pantai di Kota Makassar. Jurnal Politik Profetik, 5(2), 186-199.

Sahabat Alam Malaysia. (2019, February 26). Impacts Of Coastal Reclamation In Malaysia. Retrieved from https://www.foe-malaysia.org/impacts_of coastal_reclamation_in_malaysia, on February 25,2020 .

Sandirasegaran, K. \& Manap, N. (2016). Impacts Of Dredging And Reclamation Projects. Jurnal Teknologi, 787(7-3), 139-143.

Transnational Institute. (2014). The Global Ocean Grab A Primer. (C. Pedersen, T. Feodoroff, R. Reuter, J. Franco, N. Buxton, M. C. Barbesgaard, 
\& P. Vervest, Eds.). Amsterdam: Transnational Institute (TNI) Agrarian Justice Programme, Masifundise Development Trust and Afrika Kontakt together with World Forum of Fisher Peoples (WFFP).

Wibawa, A. P. (2017). Symbolic Battle in Benoa Bay Reclamation Bali Indonesia. International Journal of Science and Research (IJSR), 6(3), 744-749. doi: 10.21275/ART20171584.

Wiranata, I. M. A., Mardliyah, S., \& Achmad, Z. A. (2016). The Contestation of Discourses on Sustainable Development in The Controversy of Benoa Bay Reclamation. In ICoCSPA 2016 International Conference on Contemporary Social and Political Affair 2016. Universitas Airlangga, Surabaya, July 28-30, 2016, 292 300 .

Yulianti, R., Ikhwan, M., \& Zaman, N. (2015). Urgensi Pengaturan Reklamasi Pantai di Wilayah Pesisir Selatan Madura. Yustisia, 4(1), 103-121.

Yusup, M., Arshad, A. F., Abdullah, Y.120 A., \& Ishak, N. S. (2015). Coastal Land Reclamation: Implication towards development control system in West Malaysia. In The Asia-Pacific International Conference on EnvironmentBehaviour Studies. Barcelona School of Architecture, Barcelona, 31 Aug.-05 Sep., 2015, 354-361. 